Brit. J. prev. soc. Med. (1963), 17, 141-144

\title{
BLOOD PRESSURES IN THREE NEW HEBRIDES COMMUNITIES
}

\author{
BY \\ W. NORMAN-TAYLOR* AND W. H. REES $\dagger$ \\ New Hebrides, South Pacific
}

There has been increasing interest in the normal blood pressures of isolated and unsophisticated communities in the last few years. In particular, several investigators have questioned whether the rise in blood pressure with increasing age which appears to be common to all "Western" peoples is universal for mankind, and they have suggested that this rise is due to the occurrence among Westerners of a condition known as "essential hypertension", which is absent from some communities. Moreover, some workers have postulated a relationship between the incidence of essential hypertension and contact with Western civilization (Lovell, Maddocks, and Rogerson, 1960; Maddocks, 1961).

Wilson (1958) found that the expected increase in blood pressure with increasing age occurred among tea plantation workers in Assam, but Lovell and others (1960) and Maddocks (1961) found that this was not the case with Fijians and Gilbert islanders respectively. Barnes (1961) found no blood pressure over 120 systolic in 200 consecutive hospital admissions in Papua, the average being 92. In the Cook Islands, out of 491 persons of all ages, only two young women had high blood pressures (Murphy, 1955).

The writers recently had the opportunity of recording over 700 blood pressures during the course of a malaria, tuberculosis, and parasitological survey in the New Hebrides, and these data show that in these people, too, there is no obvious rise in pressure with age.

The New Hebrides comprise a group of numerous

* Public Health Officer, South Pacific Commission.

t Senior Medical Officer, British Service in the New Hebrides. large, mountainous islands, lying in the South Pacific between the Solomons and Fiji; the total population is some 50,000 persons. The native inhabitants are of "Melanesian" origin, dark skinned and woolly haired, and are divided into many tribal groups which are completely distinct from each other with regard to language and other anthropological matters. They have for the most part now all been "missionized", converted from nakedness and head-hunting to "mother-hubbards" $\ddagger$ and church-going, but their daily lives remain much as they always have done and in most respects is probably quieter than before since warfare and witchcraft have virtually vanished. The chief source of cash income is derived from the sale of copra-dried coconut. Migrant labour to the Australian plantations was abolished 50 years ago, and only around the few European settlements is there any wage-earning and purchase of European-type foods. Roughly the islanders are divided into two main types, the "salt-water" or coastal people, and the "bush" or interior people. The coastal people have been more thoroughly "missionized" and are generally cleaner, healthier, richer and better educated. The "bush" natives have come down to the coast more recently, often within the last generation. They know little of fishing; their canoes, for example, are crude imitations in which they never venture far. Their diet is more monotonous than that of the true coastal people and contains less protein. Yam, taro, and banana are the staples in both groups. Animal fat intake is low, though fat in the form of coconut oil is frequently added to food. $\S$

\# kind of cotton dress adopted by Christianized native women. $\$$ For details of diets see "Nutrition Research Conducted in the New Hebrides, during 1951" by S. Malcolm, Technical Paper No. 23, South Pacific Commission. 


\section{Selection of Populations Studied}

(1) EFATE IsLAND.-Investigations were carried out in two villages near the town of Port Vila (the administrative capital of the New Hebrides) which are in effect suburbs of Port Vila; most of their active male inhabitants are wage-earners in the town. Though there are extensive gardens and plantations of yam, taro, banana, etc., the diet is greatly supplemented by rice, tinned meat and fish, fresh meat, bread, sugar, biscuits, etc., the usual culture-contact diet pattern. Here 290 adults were seen, out of a possible adult population of 477 ; these included most of the older people, the younger ones being away at work. The general health was good, though malaria and intestinal parasites are relatively common.

(2) Maskelyne IsLands.-These islands lie off the south-east corner of Malekula Island, and are inhabited by 453 people. Out of an adult population of about 220, 177 were seen, most of the absentees being young men away at work on their plantations. These are "salt-water" people. Their general health is good, and malaria and filariasis are relatively infrequent, though they carry the usual load of intestinal parasites. Their diet appeared to be based on a good variety of staples, particularly yam, taro, banana, and coconut, with additional fish, shellfish, and occasional meat. No malnutrition was seen. They have little or no contact with the outside world, except visiting traders, officials, and missionaries. Few of them leave for employment elsewhere, and then only for short periods.

(3) South West BAY.-This is a small populated area on the mainland of Malekula Island. Although living on the coast, the inhabitants are recently arrived "bush" people. Five villages were included, giving a total population of 615 , and 246 adult blood pressures were taken from an adult population of about 350 . As in the Maskelynes, the inhabitants are unaffected by civilization, though there has been a resident missionary for the past 50 years and a trader for about as long. Their general health seems poorer, malaria being common and symptoms of malnutrition evident, particularly among children (potbelly, spindly legs, and dry skin). The diet is more monotonous, chiefly consisting of yam.

\section{METHODS}

Only persons who had passed puberty were examined. They were, as far as possible, made to remain seated for at least 5 minutes before the blood pressure was read. The standard mercury sphygmomanometer was used with the usual size cuff $\left(5 \frac{1^{\prime \prime}}{}\right)$ on either arm.
Systolic pressures were read when the first sound was heard and the diastolic when it started to fade. Readings were taken to the nearest $2 \mathrm{~mm}$. All examinations were done by the same person (W.H.R.) in the Maskelynes and South West Bay, but the observations on Efate were made by various team members.

Estimation of age remained a great difficulty, particularly at South West Bay, where many of the adults were born "in darkness" or "before", i.e. in heathen times or places. They were not sufficiently aware of local history outside their own area to enable one to use past events as an indication of age. Ages were therefore estimated on appearance, bearing in mind that these people tend to age prematurely. Questions about the age or size of children were sometimes a help. In the case of older women, it was sometimes possible to date by the menopause which was assumed to occur at the age of 50 . When in doubt the recorder consulted his colleague. Some crosscheck of the consistency of our age estimations occurred when the tuberculin tests were read several days later. Ages were again estimated, usually by a different observer, and there was a general correlation with the original estimate, through there was some variation in the 30 to 50-year groups. In particular the 40 to 49-year group seems to be deficient in the Maske lynes. Whether this is due to the difficulty of drawing a line between 30 and 50 or to the fact that this repre? sented the age of most of the absentees is not known. On the other hand it may reflect a real shortage, for example caused by the 1918 influenza epidemic.

It was not possible to measure heights and weights. However, it can be said that, in general, the people were inclined to be thin rather than fat. No cases of obesity were seen during the survey and it is rare in the islands.

\section{RESUlts}

Nineteen cases of raised blood pressure were encountered (Table I, opposite). No attempt was made to diagnose the cause; they are clustered in the $60+$ age group, especially among Efate men, but this particular sample contained an abnormally high proportion of older men. Even so the average only goes up to 134 systolic and the average diastolic is apprently not raised at all.

Table II (opposite) gives the average systolic and diastolic pressures together with the standard deviations for each age group by sex, and with a total mean. The pressures are higher than those found in Papua by Barnes (1961) and in the Cook Islands by Murphy (1955) and are similar to the figures for Fiji and the Gilbert Islands given by Maddocks (1961). 
TABLE I

READINGS FOR 19 PERSONS WITH SYSTOLIC BLOOD PRESSURE OVER 159 MM., NEW HEBRIDES, MAY 1962, BY AGE GROUP AND SEX

\begin{tabular}{|c|c|c|c|c|c|c|c|c|c|c|c|c|c|}
\hline \multirow{3}{*}{\multicolumn{2}{|c|}{$\begin{array}{lll}\text { Sex } \quad . . & \ldots \\
\text { Area } \quad . . & \ldots \\
\text { Blood Pressure }\end{array}$}} & \multicolumn{6}{|c|}{ Male } & \multicolumn{6}{|c|}{ Female } \\
\hline & & \multicolumn{2}{|c|}{ Efate } & \multicolumn{2}{|c|}{ Maskelynes } & \multicolumn{2}{|c|}{ South West Bay } & \multicolumn{2}{|c|}{ Efate } & \multicolumn{2}{|c|}{ Maskelynes } & \multicolumn{2}{|c|}{ South West Bay } \\
\hline & & Systolic & Diastolic & Systolic & Diastolic & Systolic & Diastolic & Systolic & Diastolic & Systolic & Diastolic & Systolic & Diastolic \\
\hline \multirow{6}{*}{$\underset{\text { (yrs) }}{\text { Age }}$} & $10-19$ & - & - & - & - & 160 & 100 & - & - & 170 & 90 & - & - \\
\hline & $20-29$ & - & - & 一 & - & - & - & - & - & 166 & 80 & - & - \\
\hline & $30-39$ & - & - & $\begin{array}{l}162 \\
160\end{array}$ & $\begin{array}{r}108 \\
90 \\
\end{array}$ & - & - & 160 & 100 & - & - & 160 & 90 \\
\hline & $40-49$ & - & - & - & - & - & - & 165 & 100 & - & - & - & - \\
\hline & $50-59$ & 170 & 100 & - & - & - & - & - & - & - & - & - & - \\
\hline & $60+$ & $\begin{array}{l}192 \\
162 \\
170 \\
175\end{array}$ & $\begin{array}{r}100 \\
100 \\
90 \\
90\end{array}$ & $\bar{z}$ & $\begin{array}{l}\bar{z} \\
\bar{z}\end{array}$ & $\begin{array}{l}210 \\
=\end{array}$ & $\begin{array}{l}100 \\
=\end{array}$ & $\begin{array}{l}160 \\
160 \\
-\end{array}$ & $\begin{array}{r}100 \\
90 \\
-\end{array}$ & $\begin{array}{l}160 \\
=\end{array}$ & $\begin{array}{l}100 \\
=\end{array}$ & $\begin{array}{l}170 \\
170 \\
=\end{array}$ & $\begin{array}{r}90 \\
100 \\
=\end{array}$ \\
\hline
\end{tabular}

TABLE II

MEAN BLOOD PRESSURES BY AGE AND SEX WITH STANDARD DEVIATIONS, NEW HEBRIDES, MAY 1962

\begin{tabular}{|c|c|c|c|c|c|c|c|c|c|c|c|}
\hline \multirow{3}{*}{ Area } & \multirow{3}{*}{$\begin{array}{c}\text { Age } \\
\text { Group } \\
\text { (yrs) }\end{array}$} & \multicolumn{5}{|c|}{ Males } & \multicolumn{5}{|c|}{ Females } \\
\hline & & \multirow{2}{*}{$\begin{array}{c}\text { No. } \\
\text { of } \\
\text { Subjects }\end{array}$} & \multicolumn{2}{|c|}{ Systolic } & \multicolumn{2}{|c|}{ Diastolic } & \multirow{2}{*}{$\begin{array}{c}\begin{array}{c}\text { No. } \\
\text { of } \\
\text { Subjects }\end{array} \\
\end{array}$} & \multicolumn{2}{|c|}{ Systolic } & \multicolumn{2}{|c|}{ Diastolic } \\
\hline & & & Mean & S.D. & Mean & S.D. & & Mean & S.D. & Mean & S.D. \\
\hline \multirow[t]{2}{*}{ Efate Is. } & $\begin{array}{l}10-19 \\
20-29 \\
30-39 \\
40-49 \\
50-59 \\
60+\end{array}$ & $\begin{array}{l}19 \\
28 \\
28 \\
31 \\
11 \\
26 \\
\end{array}$ & $\begin{array}{l}115 \cdot 7 \\
127.8 \\
119.0 \\
120.9 \\
127.2 \\
134.2\end{array}$ & $\begin{array}{r}11 \cdot 1 \\
6 \cdot 4 \\
27 \cdot 9 \\
12 \cdot 7 \\
19 \cdot 9 \\
25 \cdot 1 \\
\end{array}$ & $\begin{array}{l}73 \cdot 9 \\
79 \cdot 2 \\
82 \cdot 0 \\
78 \cdot 3 \\
77 \cdot 2 \\
79 \cdot 2 \\
\end{array}$ & $\begin{array}{l}20 \cdot 6 \\
12.0 \\
17.5 \\
14 \cdot 2 \\
15.0 \\
16.0\end{array}$ & $\begin{array}{r}25 \\
40 \\
36 \\
25 \\
4 \\
17 \\
\end{array}$ & $\begin{array}{l}121 \cdot 0 \\
121 \cdot 3 \\
121 \cdot 7 \\
124 \cdot 4 \\
125 \cdot 7 \\
126 \cdot 4\end{array}$ & $\begin{array}{r}15.2 \\
13.4 \\
13.4 \\
20.0 \\
5.0 \\
21.4 \\
\end{array}$ & $\begin{array}{l}74 \cdot 6 \\
75 \cdot 6 \\
73 \cdot 0 \\
76 \cdot 0 \\
87 \cdot 7 \\
74 \cdot 1 \\
\end{array}$ & $\begin{array}{r}7 \cdot 8 \\
9 \cdot 4 \\
11 \cdot 0 \\
14 \cdot 0 \\
11 \cdot 0 \\
13 \cdot 4\end{array}$ \\
\hline & Total & 143 & $124 \cdot 1$ & - & $78 \cdot 3$ & - & 147 & $123 \cdot 4$ & - & $76 \cdot 9$ & - \\
\hline \multirow[t]{2}{*}{ Maskelynes (Malekula Is.) } & $\begin{array}{l}10-19 \\
20-29 \\
30-39 \\
40-49 \\
50-59 \\
60+\end{array}$ & $\begin{array}{r}11 \\
27 \\
23 \\
6 \\
17 \\
7\end{array}$ & $\begin{array}{l}119.2 \\
119.5 \\
128.2 \\
113.3 \\
121.5 \\
120.5\end{array}$ & $\begin{array}{l}17 \cdot 1 \\
17 \cdot 2 \\
18 \cdot 3 \\
12 \cdot 3 \\
11 \cdot 0 \\
16 \cdot 8\end{array}$ & $\begin{array}{l}78 \cdot 5 \\
79 \cdot 1 \\
84.0 \\
78 \cdot 0 \\
79 \cdot 1 \\
79 \cdot 7\end{array}$ & $\begin{array}{r}14.2 \\
11.4 \\
16.5 \\
5.8 \\
12.9 \\
12.4 \\
\end{array}$ & $\begin{array}{r}24 \\
29 \\
18 \\
6 \\
5 \\
4 \\
\end{array}$ & $\begin{array}{l}126 \cdot 9 \\
127 \cdot 0 \\
118 \cdot 3 \\
127 \cdot 0 \\
144 \cdot 4 \\
130 \cdot 5\end{array}$ & $\begin{array}{l}13 \cdot 1 \\
15 \cdot 4 \\
17 \cdot 2 \\
12.5 \\
12.8 \\
24 \cdot 3\end{array}$ & $\begin{array}{l}83 \cdot 2 \\
82 \cdot 7 \\
84 \cdot 3 \\
83 \cdot 0 \\
75 \cdot 6 \\
80 \cdot 5\end{array}$ & $\begin{array}{r}10 \cdot 3 \\
7 \cdot 1 \\
10 \cdot 9 \\
8 \cdot 6 \\
10 \cdot 3 \\
16 \cdot 2\end{array}$ \\
\hline & Total & 91 & $120 \cdot 3$ & - & $79 \cdot 7$ & - & 86 & $124 \cdot 0$ & - & $81 \cdot 5$ & - \\
\hline \multirow[t]{2}{*}{ South West Bay } & $\begin{array}{l}10-19 \\
20-29 \\
30-39 \\
40-49 \\
50-59 \\
60+\end{array}$ & $\begin{array}{l}10 \\
34 \\
32 \\
20 \\
12 \\
19 \\
\end{array}$ & $\begin{array}{l}118 \cdot 8 \\
117.7 \\
121.3 \\
116.1 \\
130 \cdot 8 \\
123.8 \\
\end{array}$ & $\begin{array}{r}19 \cdot 1 \\
5 \cdot 4 \\
16 \cdot 7 \\
14 \cdot 2 \\
12 \cdot 7 \\
22 \cdot 4\end{array}$ & $\begin{array}{l}74 \cdot 0 \\
77 \cdot 3 \\
81 \cdot 1 \\
79 \cdot 5 \\
85 \cdot 5 \\
76 \cdot 3 \\
\end{array}$ & $\begin{array}{l}18 \cdot 6 \\
12.2 \\
10.7 \\
12 \cdot 2 \\
11.8 \\
13.4 \\
\end{array}$ & $\begin{array}{r}17 \\
38 \\
30 \\
15 \\
10 \\
9 \\
\end{array}$ & $\begin{array}{l}119.9 \\
116.8 \\
116.6 \\
120.9 \\
121.4 \\
136.5 \\
\end{array}$ & $\begin{array}{r}11 \cdot 5 \\
9.4 \\
13.9 \\
18.0 \\
21.0 \\
27 \cdot 2 \\
\end{array}$ & $\begin{array}{l}80 \cdot 9 \\
77 \cdot 1 \\
75 \cdot 7 \\
72 \cdot 6 \\
71 \cdot 4 \\
80 \cdot 6 \\
\end{array}$ & $\begin{array}{r}8 \cdot 8 \\
15 \cdot 0 \\
8.0 \\
5.5 \\
8 \cdot 3 \\
8 \cdot 8 \\
\end{array}$ \\
\hline & Total & 127 & $121 \cdot 4$ & - & $78 \cdot 9$ & - & 119 & $122 \cdot 0$ & - & $76 \cdot 3$ & - \\
\hline \multirow[t]{2}{*}{ Malekula Is. Combined } & $\begin{array}{l}10-19 \\
20-29 \\
30-39 \\
40-49 \\
50-59 \\
60+\end{array}$ & $\begin{array}{l}21 \\
61 \\
55 \\
26 \\
29 \\
26\end{array}$ & $\begin{array}{l}119 \cdot 0 \\
118.5 \\
124 \cdot 1 \\
115 \cdot 5 \\
125 \cdot 3 \\
123.0\end{array}$ & $\begin{array}{l}18 \cdot 1 \\
15 \cdot 9 \\
17 \cdot 2 \\
16 \cdot 2 \\
16 \cdot 0 \\
20 \cdot 7\end{array}$ & $\begin{array}{l}76 \cdot 3 \\
78 \cdot 1 \\
82 \cdot 6 \\
79 \cdot 1 \\
81 \cdot 8 \\
77 \cdot 2\end{array}$ & $\begin{array}{r}17 \cdot 0 \\
11 \cdot 1 \\
7 \cdot 7 \\
9 \cdot 3 \\
9 \cdot 0 \\
12 \cdot 1\end{array}$ & $\begin{array}{l}41 \\
67 \\
48 \\
21 \\
15 \\
13 \\
\end{array}$ & $\begin{array}{l}124.0 \\
121.3 \\
117.2 \\
122.6 \\
119.0 \\
134.6\end{array}$ & $\begin{array}{l}13.8 \\
16.0 \\
17.9 \\
14.6 \\
16.8 \\
21.7 \\
\end{array}$ & $\begin{array}{l}82 \cdot 3 \\
79.5 \\
78.9 \\
75.6 \\
72 \cdot 8 \\
80 \cdot 6 \\
\end{array}$ & $\begin{array}{r}11 \cdot 1 \\
15.9 \\
9.9 \\
6.4 \\
11 \cdot 5 \\
15.7 \\
\end{array}$ \\
\hline & Total & 218 & $120 \cdot 9$ & - & $79 \cdot 1$ & - & 205 & $123 \cdot 1$ & - & $78 \cdot 2$ & - \\
\hline
\end{tabular}

The results are shown in graphic form in Fig. 1 (overleaf); for simplicity, only two curves are drawn, the "culture-contact" curve for the Efate islanders living near Port Vila, and the "unsophisticated" curve for the two groups in Malekula. However, there is demonstrably no sigificant difference between the two. These curves are, if anything, even more horizontal than those found by Maddocks in Fiji and the Gil- 


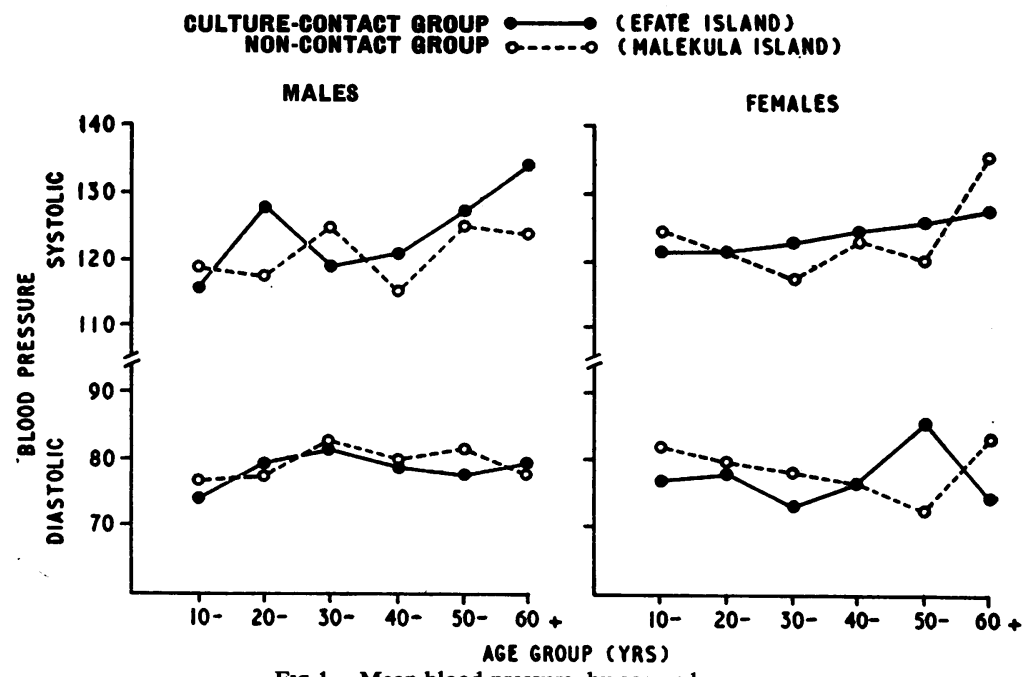

Fig 1.- Mean blood pressure, by age and sex.

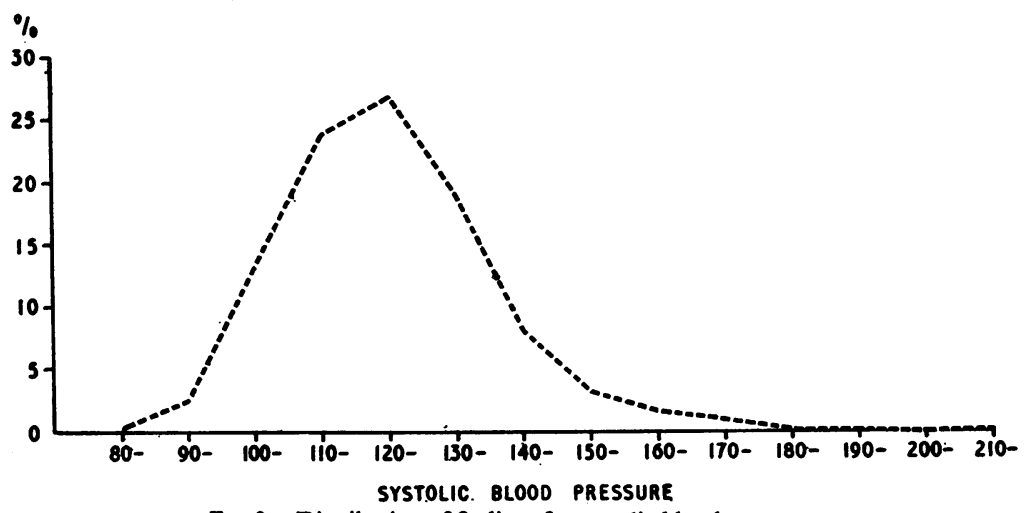

FIG 2.-Distribution of findings for systolic blood pressure.

berts. It is tempting to link this with the fact that obesity is unknown in the New Hebrides whereas there it was frequently observed. The distribution of the combined findings is given in Fig. 2 . These findings suggest that there is little or no indication of a physiological rise in blood pressure with increasing age in the New Hebrides.

\section{SUMMARY}

Blood pressures were recorded in three areas in the New Hebrides Islands in the South Pacific, one being an area in which the inhabitants are working in paid employment and eating a proportion of Western food, and the other two being areas virtually untouched by civilization. In these two latter areas 70 to 80 per cent. of the estimated adult populations were seen, most absentees being young men away at work. A total of 713 pressures were read. Although a certain number of cases of raised blood pressure were found, particularly in older people, the average systolic and diastolic pressures do not increase markedly with age in any of the three areas.

\section{REFERENCES}

Barnes, R. (1961). Med. J. Aust., $2,540$.

Lovell, R. R. H., Maddocks, I., and Rogerson, G. W. (1960). Aust. Ann. Med., 9, 4.

Maddocks, I. (1961). Lancet, 2, 396.

Murphy, W. (1955). N.Z. med.J., 54, 64.

Wilson, J. M. G. (1958). Brit. J. prev. soc. Med., 12, 204. 